\title{
Small farm dams: impact on river flows and sustainability in a context of climate change
}

\author{
F. Habets ${ }^{1}$, E. Philippe ${ }^{1}$, E. Martin ${ }^{2}$, C. H. David ${ }^{3}$, and F. Leseur ${ }^{4}$ \\ ${ }^{1}$ CNRS/UPMC/Mines-Paristech, UMR 7619 Sisyphe, 5 Place Jussieu, 75005 Paris, France \\ ${ }^{2}$ CNRM-GAME/Météo-France, 42 avenue Coriolis, 31057 Toulouse, France \\ ${ }^{3}$ University of California Center for Hydrologic Modeling, University of California, Irvine, California, USA \\ ${ }^{4}$ DREAL Pays de la Loire, Nantes, France \\ Correspondence to: F. Habets (florence.habets@upmc.fr)
}

Received: 3 November 2013 - Published in Hydrol. Earth Syst. Sci. Discuss.: 22 November 2013

Revised: 6 August 2014 - Accepted: 19 September 2014 - Published: 28 October 2014

\begin{abstract}
The repetition of droughts in France has led to a growing demand for irrigation water and consequently to an increase in requests for the construction of small farm dams. Although such dams are small, their accumulation in a basin affects river flows, because the water collected in these small farm dams is used for irrigation and thus does not contribute to river flow. In order to gain more insight into their impact on the annual and monthly discharges, especially during dry years, a small farm dam model was built and connected to a hydrometeorological model. Several scenarios with different volume capacities, filling catchment sizes and filling periods were tested for such dams. The results were analysed in a small basin in western France, where the pressure for building such dams is high, and then extended to the entire country. It was found that, due to the hydrometeorological conditions (mainly low precipitation compared to other regions in France), the development of small farm dams in north-western France would result in greater decreases in river flows and less efficient filling of small farm dams than in other regions. Therefore, such dams might not be as efficient as expected in supplying water to farmers when needed. Moreover, the ability to fill small farm dams is projected to decrease in a context of climate change, despite the uncertainty on the evolution of precipitation, thus worsening the situation.
\end{abstract}

\section{Introduction}

In recent decades, France has suffered several droughts (Vidal et al., 2010b), with considerable impacts on hydrology (Giuntoli et al., 2013) and agriculture (Amigues et al., 2006; van der Velde et al., 2012). Moreover, droughts are projected to be both more frequent and more extreme in the context of climate change (Vidal et al., 2012). Irrigation is a solution to protect farmers from water shortages, the water being provided by rivers and/or groundwater where the hydrogeological conditions are suitable, or from reservoirs elsewhere. Irrigation dams have been used for a thousand years in the Mediterranean area (Albergel et al., 2004) and have proved to be efficient in providing irrigation water in semi-arid regions, with a positive impact on the economic activity of the countries concerned (Khlifi et al., 2010). Although irrigation dams can be large, most of them are associated with reservoirs with small storage capacity located on farms, and therefore usually not connected to the main rivers, but connected to small brooks. We will use the term "small farm dams" to distinguish these dams from the larger man-made structures used for flood control and/or hydroelectricity.

Small farm dams can be seen as a potential solution to the projected increase in droughts. Indeed, it is expected that water withdrawals or derivations to fill small farm dams reduce discharge during the filling period (restricted to the high-flow period), so that the stored water can be used for irrigation in summer without affecting the discharge during low flow. For these reasons, there is growing pressure from French farmers' unions to allow for their development, with the aim 
of protecting or extending production capacities (FNSEA, 2012). One argument is that small farm dams are expected to provide water when crops need it, by storing water during the winter, which would also help to mitigate winter flood events. In France, such small farm dams are used extensively in the south-west (http://www.eau-adour-garonne. $\mathrm{fr} / \mathrm{fr} /$ etat-des-ressources-gestion-quantitative/

barrages-et-reservoirs-du-bassin-adour-garonne.html),

with a storage capacity above $800000000, \mathrm{~m}^{3}$ (Hébert et al., 2012). Such a dense concentration is quite unique in France. The economic impact of these dams was studied in detail by Hébert et al. (2012), but few studies in France have focused on their hydrological impact, with the notable exception of Galéa et al. (2005), who, by analysing the observed river flows of some basins, found that these dams mostly lead to a reduction in winter floods. When the time series of the observed river flow is too short, the methodology used by Galéa et al. (2005) cannot be applied. In such cases, modelling can be used to estimate the impact of small farm dams. One issue for such modelling is the determination of the geolocalization and volumes stored in the numerous reservoirs. Several studies have focused on determining the number and extent of small farm reservoirs using satellite data (Bhagat and Sonawane, 2011; Casas et al., 2011; Rodrigues et al., 2012; Shao et al., 2012). A few authors have been able to conduct detailed studies of the impact on hydrology, based on the simulation of a large number of small farm dams. Among them, Güntner et al. (2004) and Malveira et al. (2012) combined the explicit simulation of numerous small dams (lower than $100000 \mathrm{~m}^{3}$ ) with large dams (above $50000000 \mathrm{~m}^{3}$ ) in north-eastern Brazil, and noted that the smaller dams reduced the water yield of the larger dams. Ramireddygari et al. (2000) in the USA, Hughes and Mantel (2010) in South Africa and Nathan and Lowe (2012) in Australia, found that small farm dams induced a decrease of the annual discharge that could reach $10 \%$. Cudennec et al. (2004), using a simpler approach based on a unit hydrograph, conducted a prospective study in north-western France and found that the decrease of river flows is limited to the downstream basin.

The Pays de la Loire regional environmental agency (DREAL Pays de la Loire), responsible for authorizing the building of such small farm dams, has received an increasing number of requests over the past few years. The DREAL has therefore sought to determine the impact of such dams on river flows, so as to implement the policy that best meets the farmers' water demand while preserving the hydrological environment. The main questions are what is the maximum water volume that can be stored in the irrigation dams without having too great an impact on the annual and monthly discharges? In particular, what are the impacts on the floods occurring in autumn and which are important for the migration of fish and their morphogenic contributions? Are these dams really able to provide water to farmers during the drier years, and what is their impact on the dry year river flows?

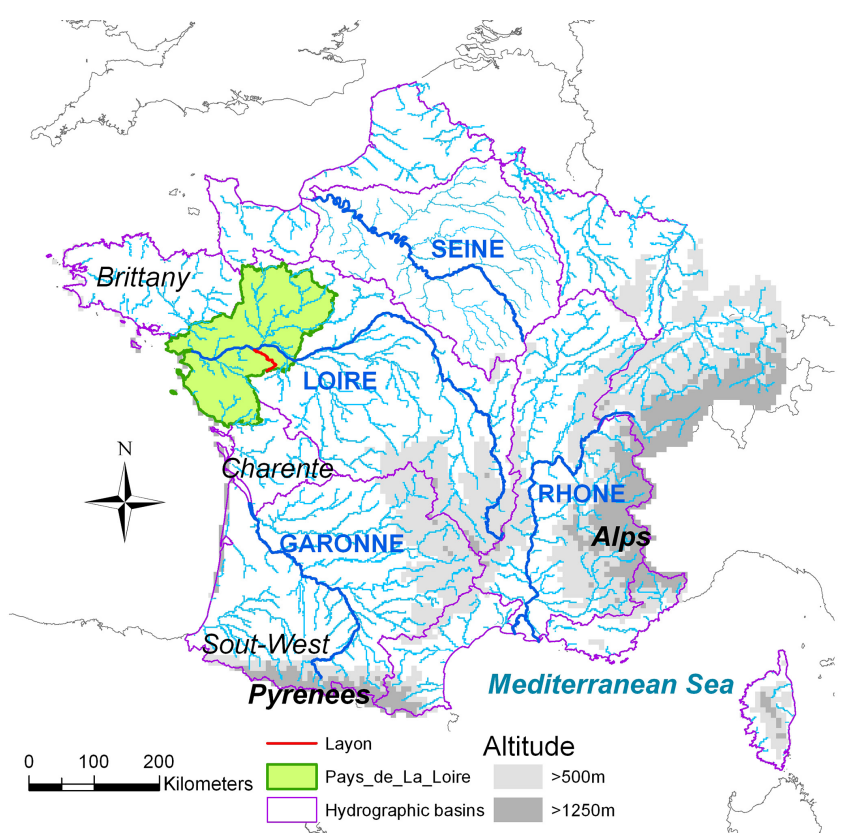

Figure 1. Domain under study. The Pays de la Loire region is shaded in green, and the Layon River is drawn in red.

Is there a need to modify the regulations with regards to the functioning of these dams, especially the authorized filling period? How can we be sure that the decisions taken at the present time will be economically and environmentally sustainable, especially in a context of climate change?

To conduct the necessary study, a physically based hydrometeorological model was used. A small farm dam module was built, with several hypotheses concerning the storage capacity and the filling capacity. This model is presented in the next section. The study first focused on the Layon Basin (Fig. 1); one economically important basin of the Pays de la Loire that sometimes lacks water for the irrigation of maize. The impacts of small farm dams on the river flows of the Layon Basin are described in detail below, as well as the ability of these dams to fill up in various climate conditions. Then, the method is generalized to the whole of France, which gives an idea of the impact of the hydrometeorological drivers. The last section considers the evolution of such anthropized basins in a context of climate change.

\section{Material and methods}

\subsection{Hydrometeorological modelling}

The method chosen used a hydrologically established model but did not calibrate it. Calibration implies the use of observed river flows, but these flows are affected by anthropization, especially by the numerous points where water is drawn from rivers and aquifers. Unfortunately, such withdrawals are not sufficiently well known to be correctly imposed within 


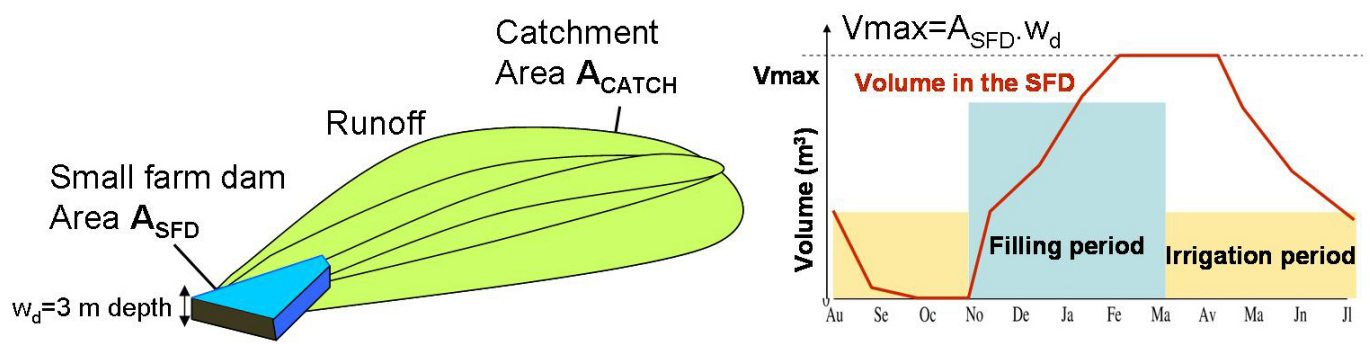

a) Schematic representation of a small farm dam (SFD)

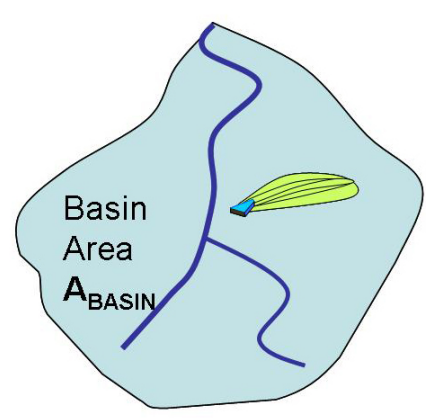

b)

Schematic representation of one SFD in a basin

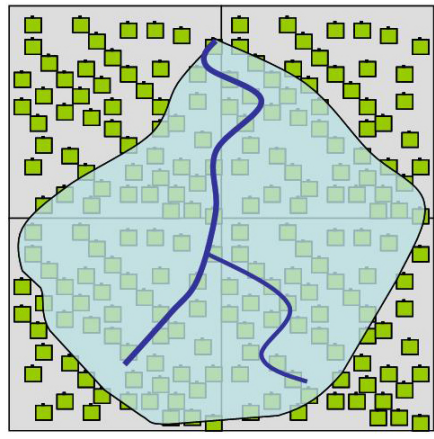

c)

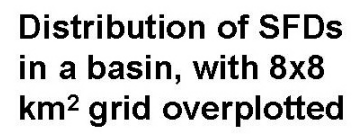

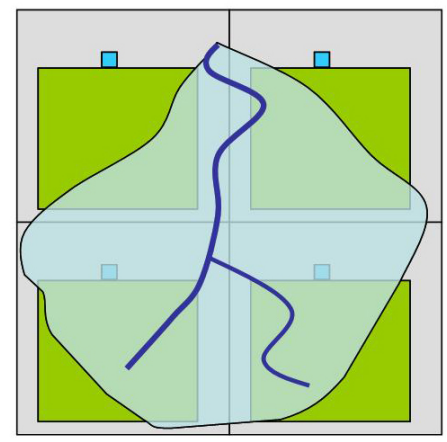

d) Equivalent representation of SFDs in the basin, distributed in a $8 \times 8 \mathrm{~km}^{2}$ grid

Figure 2. Schematic representation of a small farm dam (SFD) and its coupling with the hydrometeorological model: (a) representation of the small farm dam (in blue) and its catchment area (in green), with its volume over time according to the filling period; (b) schematic representation of an SFD in a river basin; (c) schematic representation of numerous SFDs in a basin situated in four $8 \times 8 \mathrm{~km}{ }^{2}$ cells; (d) equivalent representation of the SFD in the $8 \times 8 \mathrm{~km}^{2}$ cells of the hydrometeorological model.

the model, in spite of the great efforts made by water agencies to obtain these data. Therefore, the SIM (Safran-IsbaModcou) hydrometeorological model was used (Habets et al., 2008). In this model, the atmospheric forcing (precipitation, $2 \mathrm{~m}$ temperature and humidity, wind speed, incoming radiations) is provided by Safran (Durand et al., 1993; Quintana-Seguì et al., 2008) at an hourly time step and on an $8 \mathrm{~km}$ grid. Safran analyses are now available beginning in 1958 (Vidal et al., 2010a). The water balance was computed using the Isba atmospheric surface scheme (Noilhan and Planton, 1989), for which the parameters were derived from a physiographic database (Masson et al., 2003). Isba is coupled to the Modcou hydrological model (Ledoux et al., 2007), for which hydrogeological parameters were calibrated in the Seine and Rhone aquifers. However, since the region of interest is not deeply affected by aquifers, groundwater modelling was not used, and only surface water routing was used. The river flow was simulated using the RAPID (Routing Application for Parallel computatIon of Discharge) routing scheme (David et al., 2011a, b) for which the parameters were calibrated over the whole of France and not calibrated over a single basin. SIM was assessed for all of France (Habets et al., 2008), and one of the results was a better ability to reproduce the daily river flow of the largest basins. Quintana-Seguì et al. (2009) improved the results on the smallest basins by calibrating some soil parameters but, as mentioned above, it was decided not to use a calibrated simulation for this study. Section 3.1 presents an evaluation of the SIM results on the Layon Basin.

\subsection{The small farm dam model}

For this study, a small farm dam model was developed and connected to SIM. This model is based on several hypotheses concerning the number and location of the dams, the area and depth of the reservoirs, and their functioning (Fig. 2):

- The reservoirs are small (less than $20000 \mathrm{~m}^{3}$ ) but several small farm dams can be located in the same subbasin. Several studies have succeeded in inferring the number of dams and the area they cover using satellite data and GIS (geographic information system), (Bhagat and Sonawane, 2011; Rodrigues et al., 2012; Shao et al., 2012). Since the present study is more a prospective than retrospective study, the future location of the dams cannot be observed, and the choice was made to build simple hypotheses that could fit both the present day and the coming decades. In the Layon Basin, the number of dams is limited 
to $3 \mathrm{~km}^{-2}$ (SDAGE Loire Bretagne, 2009). However, since the water balance is computed on an $8 \mathrm{~km}$ grid by ISBA, if several dams are present in an $8 \mathrm{~km}$ grid space, they have to be considered as aggregated (Fig. 2). In a basin larger than $64 \mathrm{~km}^{2}$, the distribution of the dams can be heterogeneous. A preliminary test was used to determine whether the results were sensitive to dam locations in a $1000 \mathrm{~km}^{2}$ basin. Focusing on the river flow at the outlet, it was found that it was quite similar to take into account a few larger dams aggregated on an $8 \mathrm{~km}$ grid so as to simulate several small dams as long as they were sparsely distributed in the basin (i.e. not all located on the same tributary). This is consistent with the findings of Hughes and Mantel (2010). Therefore, for the sake of simplicity, the distribution of the dams was assumed to be homogeneous in space; i.e. there was one aggregated dam in each $8 \times 8 \mathrm{~km}^{2}$ cell used to compute the water balance.

- To estimate the volume stored in small farm reservoirs, another hypothesis was made. In the Pays de la Loire region, the spatial extent of the surface water area should not reach $5 \%$ of the basin area (SDAGE Loire Bretagne, 2009), a figure far from being achieved in most of the region's basins, even when all the natural lakes and large reservoirs are counted. The regulation is expressed as a percentage of the basin area, so we used the same formalism to express the small farm dam fraction $D$, i.e. the accumulated area of the small farm dam $\left(A_{\mathrm{SFD}}\right)$ in a basin as a percentage of the basin area $\left(A_{\text {basin }}\right.$ in $\left.\mathrm{m}^{2}\right)$ :

$D=A_{\mathrm{SFD}} / A_{\text {basin }} \times 100$.

The small farm dam fraction can be estimated using the present day irrigation water volume in the Pays de la Loire region, by considering that all the irrigation water taken from the surface water comes from small farm dams, as is the case in the Layon Basin (SAGE, 2002a). To do this, we used the pumping volume $\left(V_{\mathrm{P}}\right.$ in $\left.\mathrm{m}^{3}\right)$ provided by the basin water agency. We then needed to estimate an average water depth, $d_{\mathrm{w}}$, of small farm dams. An average value of $d_{\mathrm{w}}=3 \mathrm{~m}$ was chosen because it is the average depth of a small database referencing 171 small farm dams in south-western France, and is below the $5 \mathrm{~m}$ depth threshold for which an annual survey of the dam structure is required. Then the small farm dam fraction can be expressed as

$D=V_{\mathrm{P}} / d_{\mathrm{w}} / A_{\text {basin }} \times 100$.

Table 1 gives an estimate of this percentage for seven basins of Pays de la Loire. From Table 1, a reasonable expansion of the use of small farm dams in the future could lead them to occupy between 0.5 and $1 \%$ of the basin area.
- Although not always the case, the reservoirs are considered to be filled by capturing small brooks (even temporary brooks). These brooks are not explicitly represented in the model, but the water that flows in such brooks can be estimated by considering the surface runoff and infiltration produced on the corresponding watersheds. This approach is not fully compatible with small farm dams that are filled by pumping from rivers. Such dams are then able to collect water from a larger area than the small dam's catchment, and the chosen modelling approach will then tend to underestimate their filling ability. In any case, given that the exact locations of the small dams are unknown, it is not possible to compute their catchments. Therefore, to try to encompass these two characteristics, several catchment sizes that can contribute runoff to the dams studied here. These dam catchment areas $\left(A_{\text {catch }}\right)$ were considered to be proportional to small farm dam areas:

$A_{\text {catch }}=R \times A_{\mathrm{SFD}}$,

with $R$ varying from 20 to 200 . Since the dam's area is defined as a percentage of the basin, the area of the dam's catchment can also be expressed as a proportion of the basin area:

$A_{\text {catch }}=R \times D \times A_{\text {basin }}=C \times A_{\text {basin }}$,

where $C$ varies from 10 to $100 \%$ (see Sect. 3.2). To be compatible with filling by pumping, the inflow was limited to $1 \mathrm{~m}^{3} \mathrm{~s}^{-1}$.

- The filling period is regulated: farmers can fill the dams from November to March. However, the Pays de la Loire DREAL pays special attention to the occurrence of floods in the autumn because they have a strong positive impact on migratory fish and because they are morphogenic. Moreover, it appeared that most farmers used a shorter period to fill their dams, with increased water intake from January to March. Therefore, two filling periods were tested in this study: a 5-month period from November to March and a 3-month period from January to March.

- A strong hypothesis was made on how the dams operate: all the water in the dams is expected to be used for irrigation purposes; i.e. small farm dams are assumed to be emptied every year, and this water is taken to be spread on the fields (Fig. 2) where it is expected to evaporate with no return to the river.

- The increased water body evaporation from small farm dams was ignored, and the evaporation from the dams was considered to be equal to that of the surrounding area. The impact of this hypothesis will be discussed in Sect. 6. 
The small farm dam module was connected to SIM with a daily time step by collecting both the simulated surface runoff and infiltration that flow in their catchment areas (Fig. 2). All the flow can be captured as long as it is below the $1 \mathrm{~m}^{3} \mathrm{~s}^{-1}$ threshold and as long as the dam is not yet filled. When the dams are full or outside the filling period, the presence of dams does not affect the simulated hydrology. Hereafter the word "basin" is used for the river basin, while "catchment" is used for the dam's catchment area.

\subsection{Assessment method}

The study was conducted on two spatial scales: the local scale with a focus on the Layon Basin, and the scale extended to all of France. The basin scale makes it possible to detail the results at a fine temporal scale and to test several scenarios, while the entire-country scale provides an overview of the spatial variability and the possibility to compare with areas where small farm dams are already widely used.

The variables of interest are the filling efficiency, and the impacts on the river flow. The filling efficiency of the dams was estimated based on their maximum filling stages simulated each year according to the climatic conditions (including the dry years) compared to their maximum volume capacity. The expected decrease of the river flows associated with the presence of small farm dams was quantified on monthly and annual timescales, with particular attention paid to the low and high flows for the local scale, and on the dry years. Indeed, in case of drought, water use may be restricted by law, to the point of requisitioning water stored in dams to sustain river flow. However, the large number of small dams makes it difficult to apply this law to small farm dams, hence the advantage of quantifying their impact on flows during dry years.

To determine whether the impact of small farm dams is statistically significant, a statistical method was used. The presence of small farm dams always reduces river flows; therefore, to test the statistical significance of the results, a bootstrap approach was used. This approach can verify that the differences between the cases with and without dams are statistically significant compared to a random rearrangement of the distribution obtained with the two cases. The two samples are therefore rearranged 1000 times with mixed values, the differences between the two rearranged sets are computed, and their distribution is analysed. The results are statistically significant at the $5 \%$ level if the probability of reaching the results in the distribution is lower than or equal to $5 \%$. The same approach was used to infer the statistical significance of the results in the context of climate change.

\section{Simulation of the Layon Basin}

The study first focused on the Pays de la Loire region. Although several rivers were studied, here we concentrated on

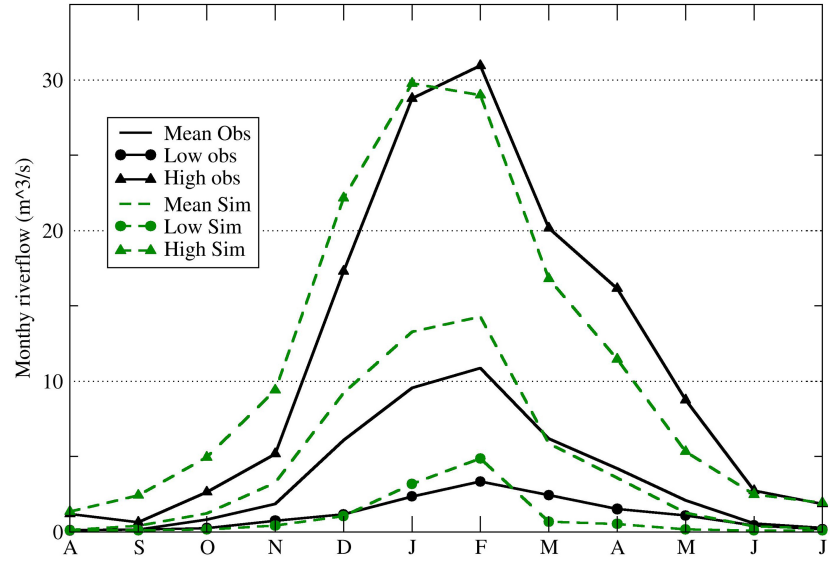

Figure 3. Comparison between observed and simulated monthly mean, high (VCX3) and low (VCN3) river flows of the Layon River at St Lambert on average for the 1970-2000 period.

the Layon Basin (Fig. 1). There are several river gauges in the Layon, and we considered the largest one, Saint Lambert $\left(930 \mathrm{~km}^{2}\right)$. The main irrigated crop is maize. The declared irrigation volume reached $3000000 \mathrm{~m}^{3}$ in 1998 (SAGE, 2002a) and had almost doubled by 2010 , with the water mostly stored in small farm dams (about $80 \%$ ) or directly pumped from the river or the alluvial aquifer (SAGE, 2002a). However, the characteristics of the existing small farm dams are not well known. An investigation in 1997 reported fewer than 180 dams larger than $2000 \mathrm{~m}^{3}$ (SAGE, 2002a). To reduce pumping in summer and its considerable effect on the region's hydrology, increasing the irrigation dam facilities in the basin is projected (SAGE, 2002b). If all the irrigation water is expected to be provided by dams, then, according to our hypotheses, the area of the reservoirs associated with small farm dams within the Layon Basin will be about $0.2 \%$ of the basin (Table 1).

Since the development of these dams from the 1970s to the present is not well known, we chose to run a simulation without small farm dams and to compare this simulation with the observations. The model is expected to overestimate the observed flow, especially during the filling period.

Then, including small farm dams in the model can account for the reduction of the river flow related to the storage of the runoff in the dams, which is considered as a loss for the hydrosystem since it is then used for irrigation. The simulated river flows are then expected to be closer to the observations, and the comparison between the two simulations allows quantifying the impact of the dams on discharge.

\subsection{Assessment of the hydrometeorological model without small farm dams}

As explained earlier, the SIM model was not calibrated to reproduce the observed river flow. The comparison with the observed river flow was made over the 1970-2000 period. 
Table 1. Estimation of the fraction of small farm dams based on known pumping pressure derived from surface water pumping in seven river basins of the Pays de la Loire region. The pumping pressure was provided by the Loire-Bretagne water agency in 2000 . A uniform water depth of $3 \mathrm{~m}$ is assumed for small farm dams.

\begin{tabular}{lrrrr}
\hline $\begin{array}{l}\text { River } \\
\text { name }\end{array}$ & $\begin{array}{r}A_{\text {basin }} \\
\mathrm{km}^{2}\end{array}$ & $\begin{array}{r}\text { Number of pumping points } \\
\text { (excluding groundwater pumping) }\end{array}$ & $\begin{array}{r}\text { Pumping pressure } \\
\text { million } \mathrm{m}^{3}\end{array}$ & $\begin{array}{r}\text { Fraction of small } \\
\text { farm dam }(D) \%\end{array}$ \\
\hline Sarthe upstream & 2827 & 133 & 3.00 & 0.035 \\
Huisne & 1833 & 218 & 1.89 & 0.034 \\
Loir & 5419 & 1565 & 17.09 & 0.105 \\
Authion & 1453 & 1268 & 23.00 & 0.528 \\
Oudon & 1341 & 167 & 2.58 & 0.064 \\
Layon & 1040 & 500 & 5.80 & 0.186 \\
Sèvre Nantaise & 2310 & 828 & 15.48 & 0.223 \\
\hline
\end{tabular}

The mean observed discharge was $4.35 \mathrm{~m}^{3} \mathrm{~s}^{-1}$, which implies that the irrigation pressure represented at least $4 \%$ of the discharge. The simulated river flows show a clear overestimation of the river flow from September to February (Fig. 3); the mean annual error on the discharge being $13 \%$, while the error from November to March reaches $23 \%$. There was slightly better agreement with the monthly low flows (VCN3: minimum 3-day river flow) and high flows (VCX3: maximum 3-day river flow), although the low flow tended to be underestimated. The daily efficiency (Nash and Sutcliffe, 1970) reached 0.61, and the efficiency computed from November to March was only 0.56 .

Although it is clear that part of the error is related to a poor estimation of the parameters describing the basin characteristics and to the physics of the model, part of the error is expected to be related to the presence of small farm dams. Indeed, between 25 and $50 \%$ of the error can be related to the water intake (depending on the reference period for the water uptake). There is still about $50 \%$ of the overestimation that is not directly linked to the water uptake. The consequences of this overestimation of the river flows during the filling period is that the simulated ability to fill small irrigation dams might be overestimated while the impact of the water withdrawals on the river flows might be underestimated.

\subsection{Impacts of the small farm dams in the Layon Basin}

Several scenarios for the extent and configuration of the dams were used: two filling periods, two maximum storage capacities, and three areas of the contributing catchment were tested (Table 2). Only the smallest dam catchment was expected to be incompatible with dams that were filled by pumping. The impacts were estimated using a 30-year simulation, from 1970 to 2000.

\subsubsection{Storage efficiency}

Only the smallest dam catchment showed poor filling ability in the Layon Basin (Fig. 4), with dams full less than 1 year out of 10 while the full capacity was reached in at least 7 out

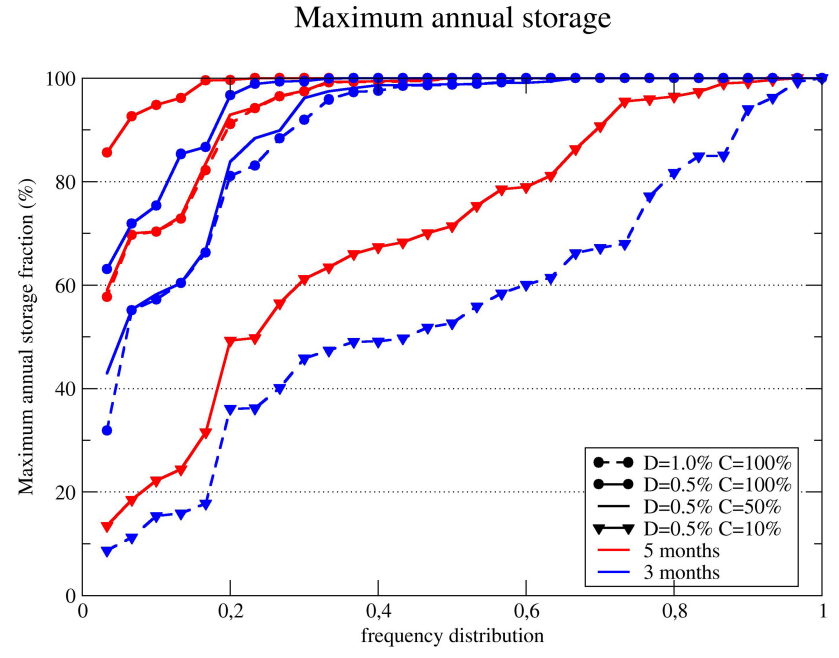

Figure 4. Frequency distribution of the maximum annual dam storage expressed as a fraction of the maximum capacity according to the filling period ( 3 or 5 months), the spatial extent of the dams $(D=1$ or $0.5 \%)$ and the size of the catchments $(C=10,50$ or $100 \%)$.

of 10 years for the other scenarios. Therefore, the smallest dam catchments are probably not economically efficient, and larger dam catchments or pumping facilities should be preferred in the Layon Basin. For the larger catchments, when the full capacity was not reached ( 3 out of 10 years), the storage was more efficient when the filling period lasted 5 months rather than 3 months. Similar results were obtained when the area of the dams represented $0.5 \%$ and the catchment area $50 \%$ of the basin area or when the dam area was $1 \%$ and the catchment area $100 \%$ of the basin, which was to be expected since the dam catchment areas are then similar (Table 2).

\subsubsection{Impact on river flows}

During the filling period, the dams are expected to capture all the water that flows on their topographic catchment as long as 
Table 2. SFD properties used to study the impact on the Layon Basin $\left(930 \mathrm{~km}^{2}\right)$. The values refer to the entire Layon Basin. The driest year is 1991-1992. The filling periods 5 and $3 \mathrm{~m}$ stand for the 5 and 3-month periods, respectively.

\begin{tabular}{lrrrrrrrr}
\hline $\begin{array}{l}\text { Filling } \\
\text { period }\end{array}$ & $\begin{array}{r}\text { SFD ratio } \\
D \%\end{array}$ & $\begin{array}{r}V_{\max } \\
\text { million } \mathrm{m}^{3}\end{array}$ & $\begin{array}{r}\text { Catchment } \\
\text { to SFD ratio } R\end{array}$ & $\begin{array}{r}A_{\text {catch }} \\
\mathrm{km}^{2}\end{array}$ & $\begin{array}{r}\text { Catchment } \\
\text { ratio } C \%\end{array}$ & $\begin{array}{r}\text { Impact on } \\
\text { the annual } \\
\text { discharge } \%\end{array}$ & $\begin{array}{r}\text { Storage } \\
\text { ratio driest } \\
\text { year } \%\end{array}$ & $\begin{array}{r}\text { Impact } \\
\text { discharge driest } \\
\text { year } \%\end{array}$ \\
\hline $5 \mathrm{~m}$ & 1 & 2.79 & 100 & 930. & 100 & -17.3 & 57.7 & -57.2 \\
$5 \mathrm{~m}$ & 0.5 & 1.395 & 200 & 930. & 100 & -9.0 & 85.6 & -40.6 \\
$5 \mathrm{~m}$ & 0.5 & 1.395 & 100 & 465. & 50 & -8.6 & 59.0 & -29.0 \\
$5 \mathrm{~m}$ & 0.5 & 1.395 & 20 & 93. & 10 & -6.4 & 13.5 & -6.9 \\
$3 \mathrm{~m}$ & 1 & 2.79 & 100 & 930. & 100 & -16.7 & 31.9 & -34.9 \\
$3 \mathrm{~m}$ & 0.5 & 1.395 & 200 & 465. & 100 & -8.7 & 63.1 & -28.6 \\
$3 \mathrm{~m}$ & 0.5 & 1.395 & 100 & 465. & 50 & -8.4 & 42.9 & -20.0 \\
$3 \mathrm{~m}$ & 0.5 & 1.395 & 20 & 93. & 10 & -5.4 & 8.7 & -4.0 \\
\hline
\end{tabular}
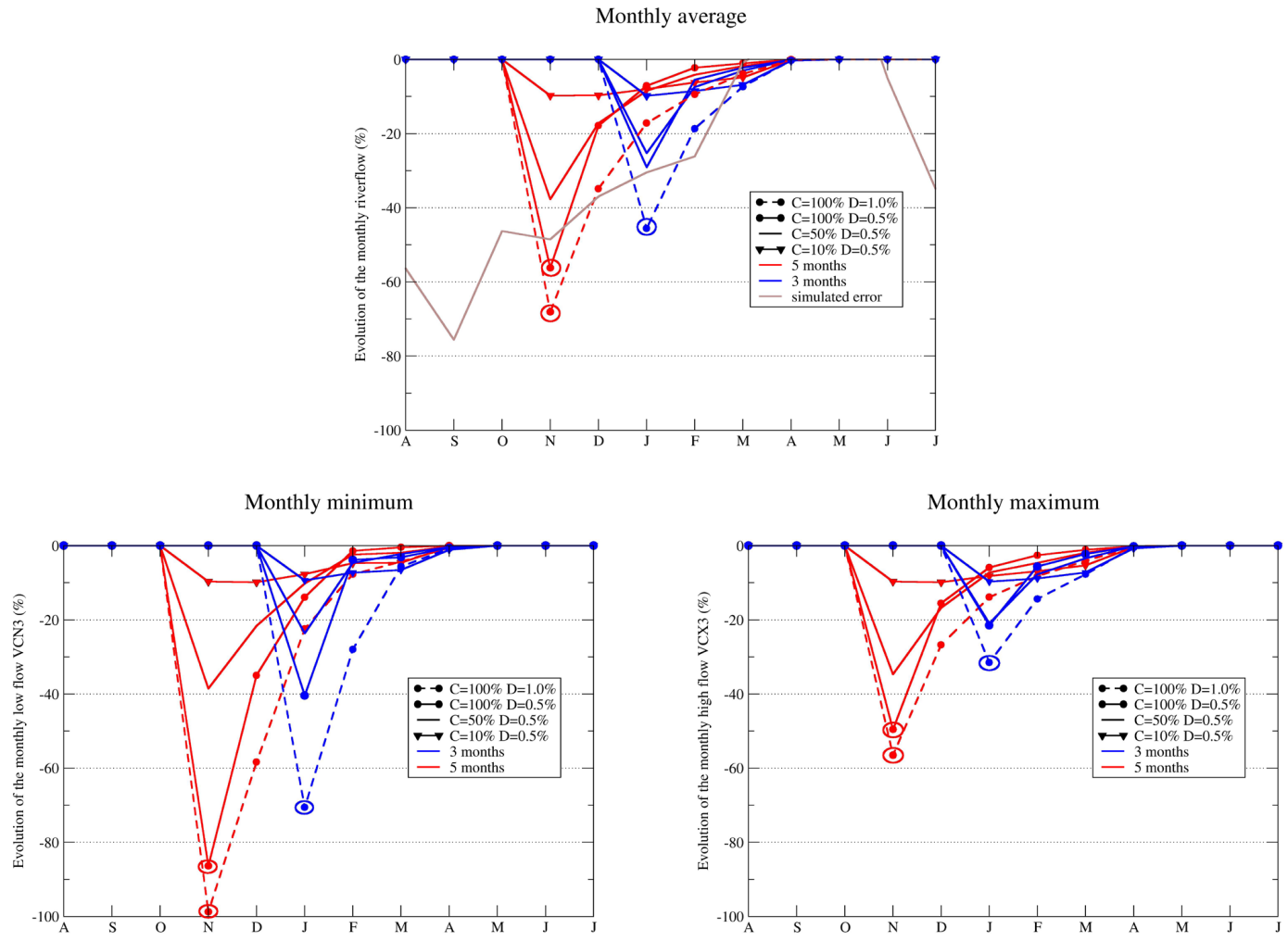

Figure 5. Impact of the irrigation dams on the mean monthly river flow (top), mean monthly low flow (bottom left) and mean monthly high flow (bottom right) of the Layon River at St Lambert according to the filling period ( 3 or 5 months), the spatial extent of the dams $(D=1$ or $0.5 \%)$ and the size of the filling catchments $(C=10,50$ or $100 \%)$. The grey line represents the error on the monthly discharge of the 10 -year reference simulation. A circle indicates that the impact is significant at $95 \%$.

the inflow is below $1 \mathrm{~m}^{3} \mathrm{~s}^{-1}$ and as long as the dams are not full. Quite logically, Fig. 5 shows that the reduction of the discharge due to the presence of the dams is greater in the first month of the filling period, except for the scenario with the smallest dam catchment, which has already been shown not to be the most suitable. The decrease of the discharge on the first month was lower for the 3-month period than for the 5-month period because the river flows were higher in January than in November.

The impacts were significant at a $95 \%$ interval only for the first month for the scenario in which the catchment covered $100 \%$ of the basin. The dam catchment area has a large impact on the intensity of monthly river flow reduction, with a maximum reduction of the flow varying from 56 to $38 \%$ for catchment areas covering 100 and $50 \%$ of the basin, 
Impact on the annual discharge

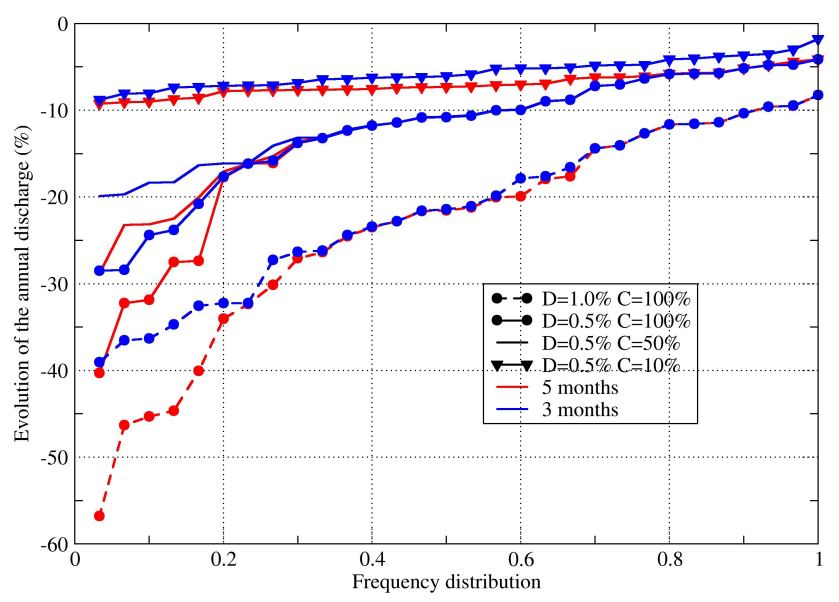

Figure 6. Frequency analysis of the impact of the small farm dams on the annual river flow according to their storage capacity and the impact of the size of the filling catchment.

respectively, for a 5-month filling period, and is limited to between 29 and $25 \%$ for a 3-month filling period. Similar results were found for the low and high river flows (VCN3 and VCX3), but with a greater impact on the low flows. Therefore, compared to a 5-month period, a 3-month period has a reduced impact on the monthly river flow while being almost as efficient for filling the dams (Table 2).

The impact of the dams on the annual discharge varied every year according to the hydrometeorological conditions. The frequency distribution of the decrease of the annual discharge associated with the presence of small farm dams is presented in Fig. 6. The largest extent $(D=1 \%)$ reduced the annual discharge by up to $20 \%$ in 6 out of 10 years. Such a strong impact might not be acceptable for the local hydrologic environment.

\subsubsection{Focus on a dry year}

Given that the irrigation dams are intended to supply water in a context of shortage, we focus here on one of the driest years. Figure 7 presents the impact on the monthly flow in 1991-1992. When the dam area was $0.5 \%$ of the basin area, the flow of the first month of the filling period was reduced by more than $90 \%$ for a dam catchment as large as the basin and around $50 \%$ for a dam catchment covering half the basin, for both filling periods. On an annual basis (Table 2), the best filling efficiency was achieved for a 5-month filling period and a $0.5 \%$ dam area with a catchment covering the full basin $(85.6 \%)$. Halving the size of the catchment limited the storage efficiency to $60 \%$. The decrease of the annual discharge was considerable, -40 and $-30 \%$, respectively, for the twodam implementations discussed above. The 3-month filling period resulted in a reduced impact on the monthly river flow, but also lowered the efficiency of dam filling during the dri-
1991-1992

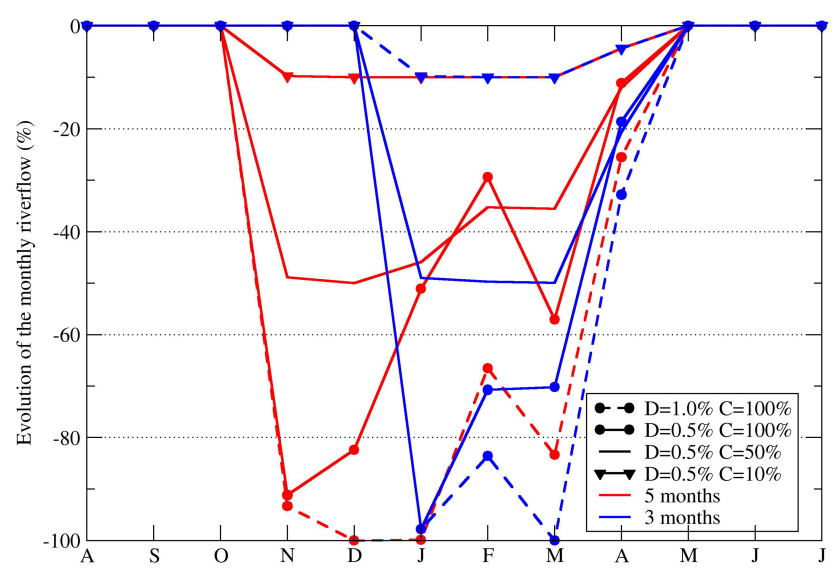

Figure 7. Impact of the small dams on the monthly river flows of the Layon River at St Lambert for the dry year 1991-1992.

est years. From this study, it seems that a $0.5 \%$ area with catchments covering all or half the basin are the most stable scenarios, with rather good filling efficiency even during dry years.

\section{Results over all of France}

The extension of the results over the whole of France allows some comparisons to be made with areas where the irrigation dams are already well developed (south-western France). Of course, an even distribution of small farm dams is not realistic. Moreover, in some regions such as part of the Seine Basin, and the Rhine and Rhone alluvial valleys, pumping from regional aquifers might be preferred to small farm dams, but the use of a spatially homogeneous scenario gives better insight into the hydroclimatic constraints on a small farm dam's filling capacity and their impact on river flow. In this section, only the scenarios with a $0.5 \%$ area for small farm dams are used, and the sensitivity to the dam's catchment and the filling periods are studied. Mean annual precipitation in France ranges from about 500 to about $2500 \mathrm{~mm}$ year $^{-1}$, with high precipitation in the mountains, and low precipitation in most of the north-west and in the Mediterranean area (Fig. 8). Such contrasts will of course impact the efficiency with which the dams are filled and also their impact on river flow. Figure 8 shows that the Pays de la Loire region is associated with relatively low rainfall.

The mean filling efficiency shows large spatial variation when averaged over the 30-year period and for the dry year of 1991-1992 (Figs. 4 and 10). In the south-west and Brittany, maximum capacity is reached for all catchment sizes and the two filling periods even for the driest year, confirming that the hydroclimatic conditions are favourable in these regions. The mountainous regions with substantial snowpack (Alps, Pyrenees) have a low filling ratio, which is related to 
Table 3. Simulated present-day precipitation and river flow according to the climate models and projections for 2050. PRCP: annual precipitation; $D$ no dams: annual discharge without small farm dams; $D 3$ and $D 5 \mathrm{~m}$ : annual discharge with small farm dams covering and area of $0.5 \%$, with a dam catchment of $50 \%$, and the 3-month and 5-month filling periods, respectively. The changes in river discharge in 2050 were computed using two references, with (in brackets) or without dams in present day; Sto: mean annual maximum storage over maximum storage of the dams for the two filling periods. Two values are computed over France: the average is computed over the whole of France and, in bold, only on the grid cells below $1250 \mathrm{~m}$. The results obtained using the Safran analysis are given as a baseline.

\begin{tabular}{|c|c|c|c|c|c|c|}
\hline & \multicolumn{3}{|c|}{ Layon } & \multicolumn{3}{|c|}{ France } \\
\hline & ARPEGE & GFDL0 & MRI & ARPEGE & GFDL0 & MRI \\
\hline & \multicolumn{6}{|c|}{$1970-2000$} \\
\hline PRCP & \multicolumn{3}{|c|}{ SAFRAN $=660$} & \multicolumn{3}{|c|}{ SAFRAN $=950$} \\
\hline mm year $^{-1}$ & 638.8 & 692.6 & 690.0 & 930 & 961 & 963 \\
\hline$D$ no dam & \multicolumn{3}{|c|}{ SAFRAN $=4.7$} & \multicolumn{3}{|c|}{ SAFRAN $=77.7$} \\
\hline $\mathrm{m}^{3} \mathrm{~s}^{-1}$ & 3.7 & 4.1 & 4.6 & 70.0 & 74.2 & 74.4 \\
\hline \multicolumn{7}{|l|}{$D$ with dam } \\
\hline $5 \mathrm{~m} \mathrm{~m}^{3} \mathrm{~s}^{-1}$ & 3.3 & 3.7 & 4.2 & 67.4 & 71.5 & 71.7 \\
\hline \multirow[t]{2}{*}{$3 \mathrm{~m} \mathrm{~m}^{3} \mathrm{~s}^{-1}$} & 3.4 & 3.7 & 4.2 & 67.4 & 71.6 & 71.8 \\
\hline & \multicolumn{6}{|c|}{$2046-2065$} \\
\hline PRCP \% & -6.3 & +3.7 & -0.1 & -13.6 & -3.7 & -5.1 \\
\hline$D$ no dam $\%$ & -22.9 & -7.3 & -34.6 & -30.6 & -14.8 & -20.7 \\
\hline$D 5 \mathrm{~m} \%$ & $-32.4(-24.8)$ & $-17.2(-8.2)$ & $-42.2(-36.6)$ & $-34.3(-31.7)$ & $-18.4(-15.5)$ & $-24.2(-21.4)$ \\
\hline$D 3 \mathrm{~m} \%$ & $-31.7(-24.4)$ & $-16.3(-7.6)$ & $-41.2(-35.7)$ & $-34.1-31.6$ & $-\mathbf{1 8 . 3}-15.3$ & $-\mathbf{2 4 . 0}-21.4$ \\
\hline Sto $5 \mathrm{~m} \%$ & -2.2 & 0. & -2.4 & $-\mathbf{3 . 5}+14.2$ & $-\mathbf{0 . 9}+3.2$ & $-\mathbf{1 . 4}+5.9$ \\
\hline Sto $3 \mathrm{~m} \%$ & -3.7 & -0.2 & -6.4 & $-\mathbf{5 . 0}+19.6$ & $-\mathbf{3 . 0}+11.5$ & $-\mathbf{5 . 2}+18.6$ \\
\hline
\end{tabular}

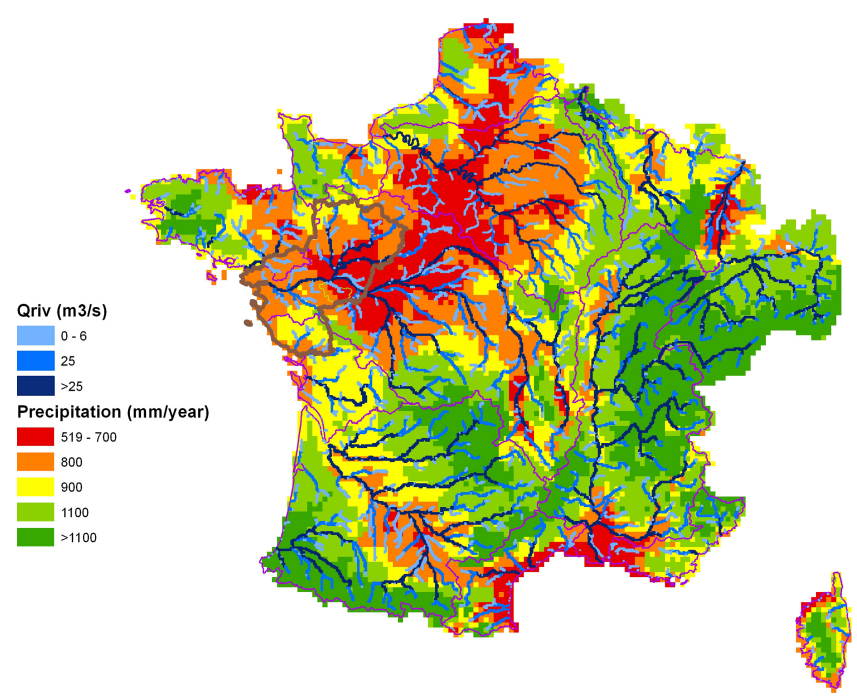

Figure 8. Mean annual precipitation from the Safran analysis $\left(\mathrm{mm}_{\mathrm{m}} \mathrm{r}^{-1}\right)$ and mean annual river flow $\left(\mathrm{m}^{3} \mathrm{~s}^{-1}\right)$ simulated by SIM for the 1970-2000 period. The Pays de la Loire region is outlined in brown.

the fact that, during the filling period, the water is stored in the snowpack. Actually, numerous hydropower dams exist in these mountainous regions, with quite different filling periods, since the captured flow is provided by snowmelt rivers. Other regions such as the Seine Basin and the Pays de la
Loire region have a low mean annual filling ratio $(50 \%)$ for the smallest catchment, and presented a lower filling ratio during the 1991-1992 dry year for all catchment sizes and filling periods. The 3 -month filling period resulted in similar mean filling ratios over France for the two larger catchment sizes but was shown to be less efficient during drier years than the 5-month period (Fig. 10).

The impacts on the discharge averaged over the 30-year period and for the dry year are presented in Fig. 11 for one medium scenario $(D=0.5 \%, C=50 \%, 5$-month filling period) only, because similar results were found for the others. The impact on river discharge is lower than $2 \%$ in the Alps and Pyrenees areas, where small farm dams were not able to fill. More surprising, the mean decrease of the annual discharge was also lower than $2 \%$ in south-western France even though the dams there have a high mean annual filling ratio. In contrast, the decrease of the mean annual discharge was greater than $5 \%$ in most parts of the Seine Basin, Pays de la Loire region, and along the Garonne River, and exceeded $10 \%$ in some parts of these regions. When we focus on the dry year, the Pays de la Loire region and Seine Basin stand out as places where the impact was greatest, above $15 \%$.

These results show that small farm dams have the smallest impact on the discharge and the best storage efficiency in south-western France, where they are numerous. This is related to the high precipitation in this area, especially during the filling period. These results emphasize that, due to 
the variability of the hydroclimatic conditions, the management developed in the south-west may be less efficient and may have a greater impact in the river discharge of the Seine Basin and Pays de la Loire regions.

\section{Projection in a context of climate change}

To form an idea of the sustainability of small farm dams in the context of climate change, three downscaled climate projections were used to estimate how the storage efficiency and the impact on the river flows could evolve. The downscaled projections had already been used over France (Boé et al., 2009; Chauveau et al., 2013; Habets et al., 2013), which allowed three contrasting projections to be selected. The three downscaled projections share the A1B emission scenario and a weather typing downscaling method (Boé et al., 2006; Pagé et al., 2008). Two time periods were used: 1970-2000 for the present day and 2045-2065 for the future. The precipitation projected by the three downscaled projections on the Layon Basin and over the whole of France are presented in Fig. 12 and Table 3. ARPEGE (Action de Recherche Petite Echelle Grande Echelle) gives the driest projection, with a decrease in precipitation that reaches $13.6 \%$ on average and with significant evolution over most of France, while GFDL0 (Geophysical Fluid Dynamics Laboratory) is the projection with the least change $(-3.7 \%)$ and no significant change over France. In the Layon Basin, the same observations can be made, ARPEGE is the driest projection while GFDL0 is the wettest one. In the following, the impact of climate change on the Layon Basin with small farm dams is presented first, and then the focus is extended to the whole of France.

\subsection{Combined impacts of small farm dams and climate change on the Layon Basin}

Climate change alone is projected to have a strong impact on the river flow of the Layon Basin, with rather large uncertainty: the annual discharge is projected to decrease by $7-$ $34 \%$ (Table 3). The presence of small farm dams both in the present day and in 2050 resulted in a more pronounced decrease, from -8 to $-36 \%$, and if the small farm dams were considered to be developed by 2050 but not to exist in present day, the decrease was more pronounced, from -16 to $-42 \%$. The impacts of (i) climate change alone and (ii) both climate change and dams, on the monthly discharge compared to the present day without dams, are presented in Fig. 13. Although the climate projections show considerable dispersion, the impact of climate change and small farm dams in the first month of the filling period was substantial, with a decrease of the discharge ranging from -40 to $-80 \%$ in November for a 5 -month filling period and from -30 to $-50 \%$ in January for a 3-month filling period. Comparing the results in 2050 with and without small farm dams, the impact of the dams was significant at a $95 \%$ level only in the first month for the
ARPEGE projection and was not significant for the other two projections.

The impact of small farm dams was partly limited by a decrease in their ability to fill for all projections except GFDL0 (Fig. 14). On average, over the three projections, for a 5month filling period, full storage was reached in 6 years out of 10 in the present day, but only in 4 years out of 10 in 2050, the small farm dams being projected to be less than $70 \%$ full for 2 years out of 10 in 2050. The impact of climate change was accentuated for a 3-month filling period, the small farm dams projected to be full for 3 years out of 10 in 2050, and to be less than $50 \%$ full for 2 years out of 10 in 2050 .

\subsection{Combined impacts of small irrigation dams and climate change in France}

When the view is widened to the whole of France, we find that, although the climate projections were rather different, the regions that were found to be the most sensitive to drier years in the present day were the most impacted by climate change. A strong decrease (above $15 \%$ ) in storage was found in the Seine Basin, the centre of the Garonne Valley, the south of the Loire Basin, and the Pays de la Loire (Fig. 15). Regions with a large snowpack in the present day were projected to improve their storage capacity in 2050 due to a diminution of the snowpack (Alps and Pyrenees mountain ranges). However, as stated before, hydropower dams are present today in these mountainous regions, they are not affected by the same regulation as small farm dams, and most particularly, their filling periods are not fixed. Therefore, the results obtained in these regions should not be considered. This is why, in Table 3 , the results on the evolution of the filling capacity are given for the area below $1250 \mathrm{~m}$ (93\% of France), as well as on the whole of France. The filling efficiency presented a more extensive and greater decrease when the filling period was reduced to 3 months (Table 3). For instance, the proportion of the country where the filling efficiency decreased by up to $10 \%$ was almost doubled when the filling period was reduced to 3 months instead of 5 (Fig. 15). The results were significant in the Garonne Valley for the MRI (Meteorological Research Institute) and ARPEGE projections, and also over part of the Seine Basin for ARPEGE.

The impact of climate change alone on the annual discharge showed a more contrasted spatial pattern (Fig. 16). Two of the three scenarios projected an increase of the river flow in the south of France (although the increase was not significant at the $95 \%$ level), while the third one projected a small change in flow in the Charente Basin. On average, over France, the river flows were projected to decrease by about $15-30 \%$ (Table 3). Figure 16 shows the impact of small farm dams in the annual discharge in 2050 compared to the simulation in 2050 without small farm dams (the results for a 5-month filling period are presented, but similar results were found for a 3-month period). It can be seen that, although the impact of climate change alone is rather different 

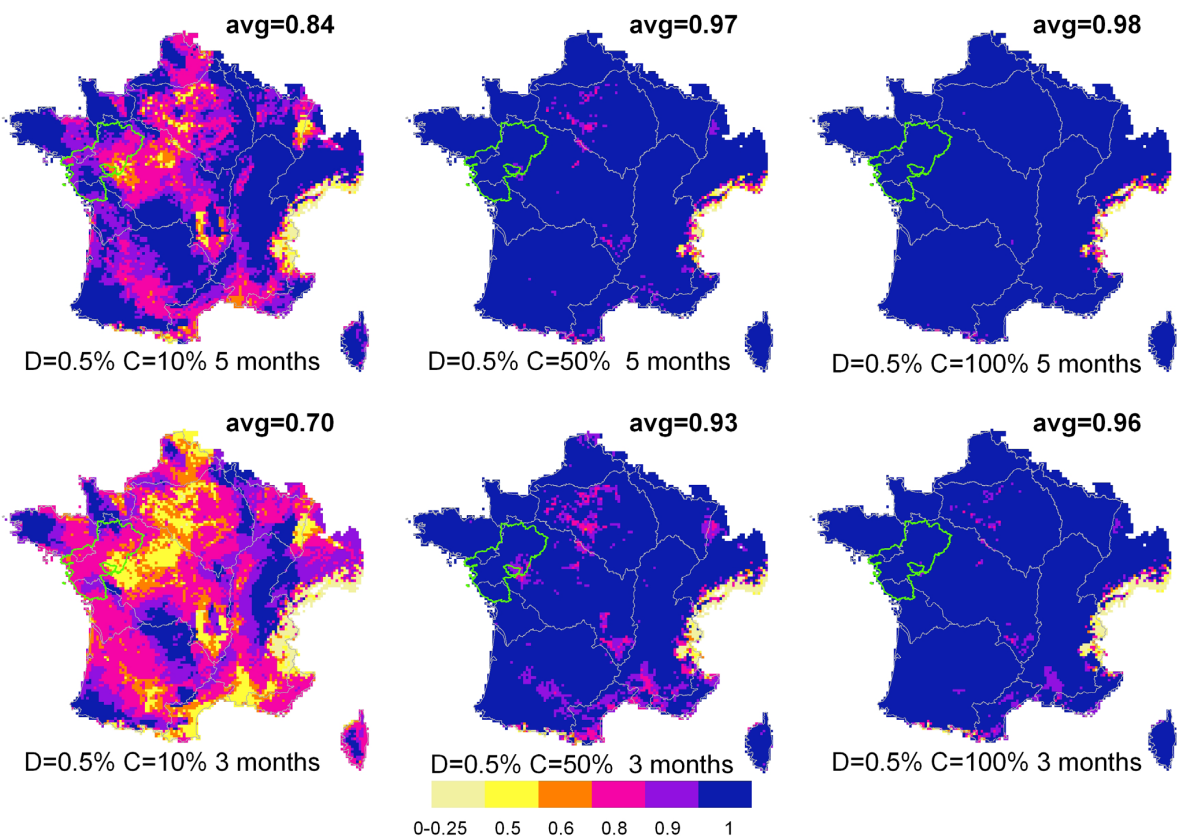

Figure 9. Mean maximum storage fraction of the dams over the 30-year period for 5-month (top) and 3-month (bottom) filling periods. The Pays de la Loire region and the Layon Basin are outlined in green.
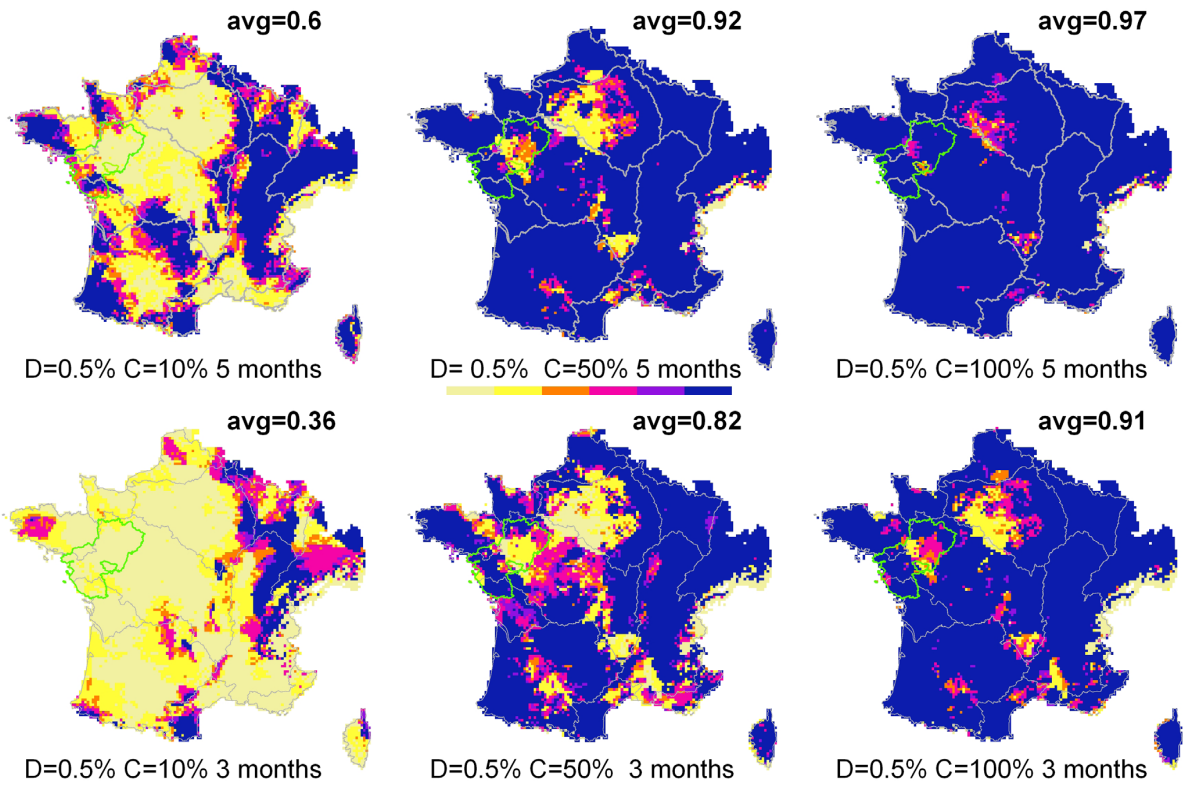

Figure 10. Mean maximum storage fraction of the dams over the dry year of 1991-1992 for 5-month (top) and 3-month (bottom) filling periods. The Pays de la Loire region and the Layon Basin are outlined in green.

between the three projections, the impact of small farm dams in the context of climate change has the same spatial pattern as at present day, but with greater intensity. However, these changes are not significant at the $95 \%$ level.

\section{Discussion}

Using a simple model of small farm dams and several hypotheses, this study was able to estimate the impact on the river flows of extended small farm dams spread over the Pays de la Loire region, and to compare the results for this region with those for the rest of France, especially with the 

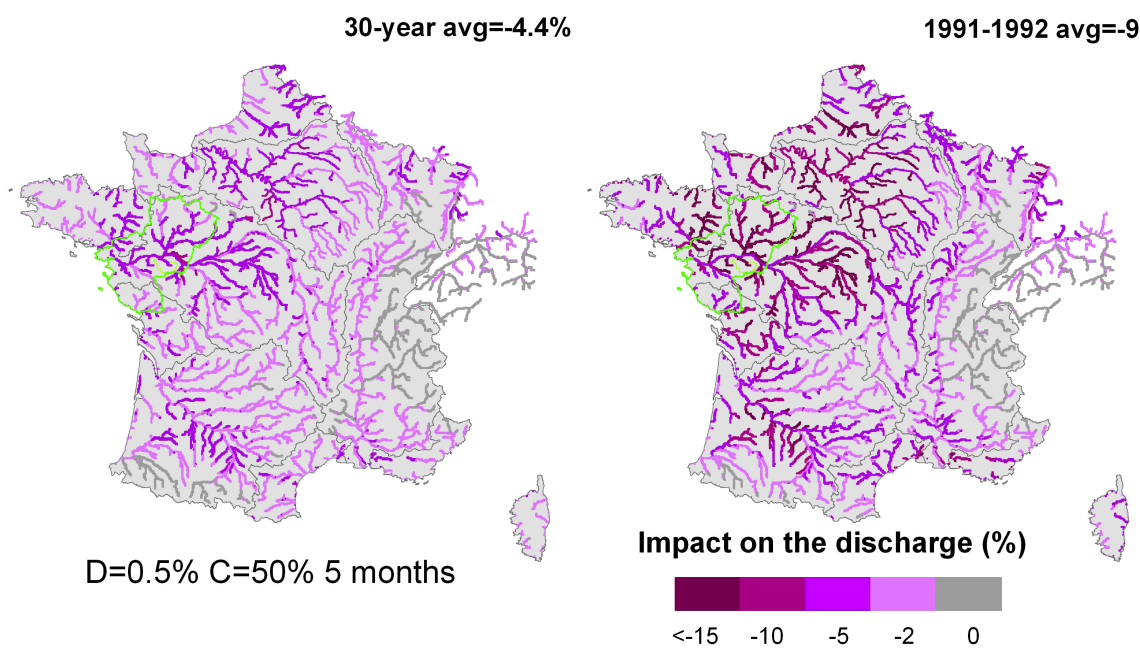

Figure 11. Mean impact of small farm dams on the annual discharge for a 5-month filling period, a $0.5 \%$ coverage, and a $50 \%$ dam catchment. The Pays de la Loire region is outlined in green.
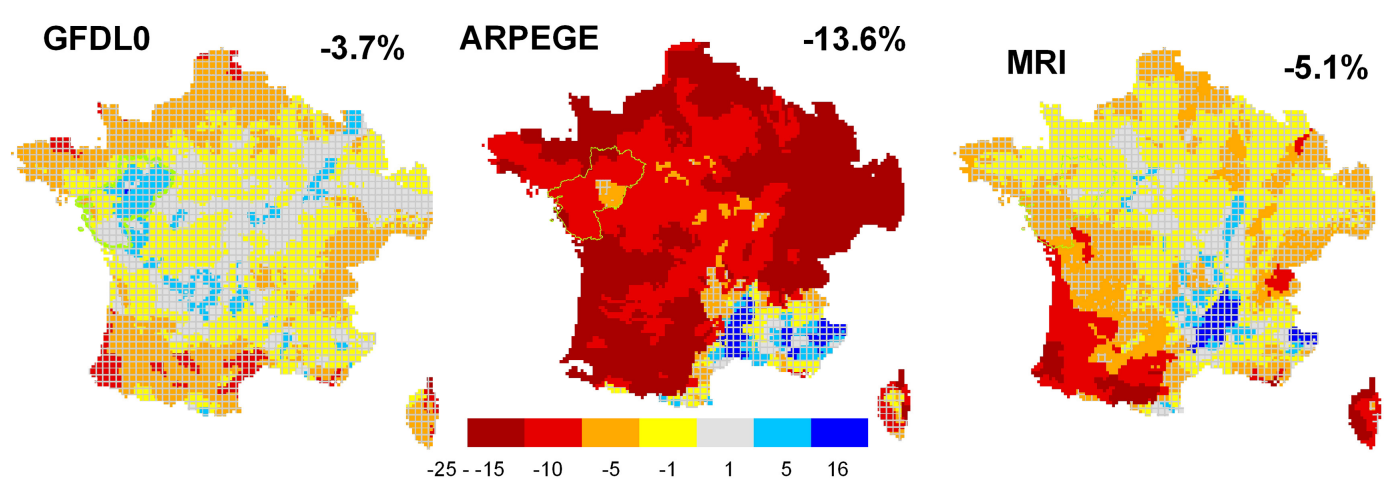

Figure 12. Evolution of annual average precipitation (in \%) for the period 2045-2065 compared to 1970-2000 for the three climate projections. Changes that are not significant at the $95 \%$ level are hatched.

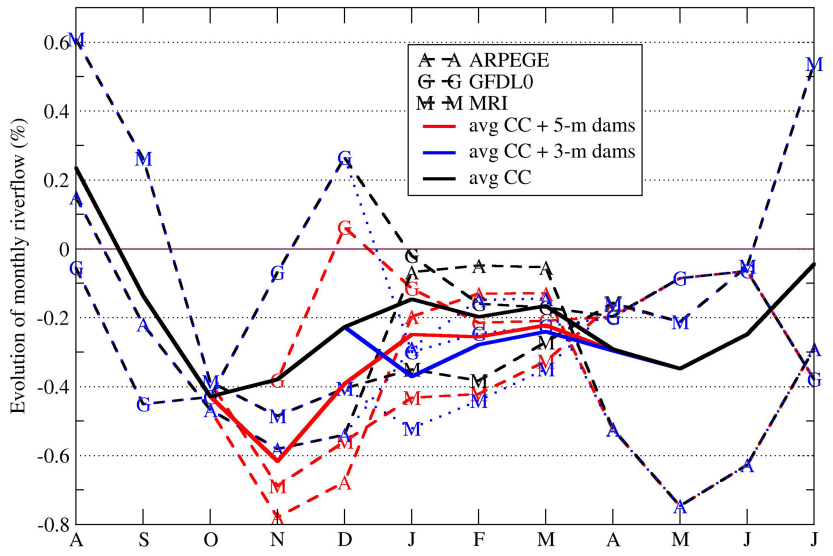

Figure 13. Evolution of the Layon monthly river flows according to three climate projections with (black) and without small farm dams (blue for the 3-month filling period, red for the 5-month filling period). The solid lines are averages over the three climate projections. regions where such dams are already highly developed. In the Pays de la Loire region, it was found that large-capacity storage dams would have a considerable impact on the river discharge (decrease above $15 \%$ ) and would need to collect water from the whole basin if they were to be completely filled. Smaller-capacity storage dams would have a reduced impact on the annual discharge (decrease above $7 \%$ ), but would still need to collect water from a large part of the basin to be able to be fill efficiently. These results are consistent with the findings of Hughes and Mantel (2010) and Nathan and Lowe (2012). It was also shown that a 3-month filling period reduced the impact on the monthly discharge (and of course on floods occurring in autumn), but resulted in greater filling failure during drier years. Moreover, these failures are projected to increase in the context of climate change. The Pays de la Loire region was shown to be one of the regions of France where the decrease of river discharge due to the presence of small farm dams is the greatest and where the ability of these dams to supply water to farmers is the lowest. 


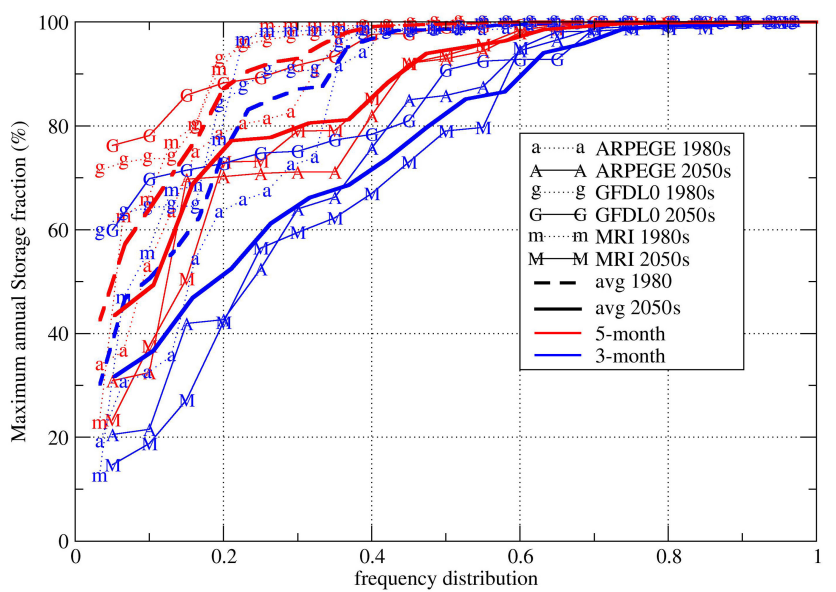

Figure 14. Comparison of the frequency distribution of the maximum annual storage of small farm dams on the Layon in the 1980s and 2050s as simulated using three downscaled climate projections, for the 5-month (red) and 3-month (blue) filling periods. The letter corresponds to the climate model (lower case for 1980s, upper case for 2050s), and the averages in 1980 and 2050 are outlined in thick dashed and solid lines, respectively.

However, this study was based on several hypotheses that influenced the results. First, the water balance was estimated by the SIM hydrometeorological model, which is, of course, imperfect. In fact, SIM was shown to overestimate the river flow of the Layon Basin, and this error cannot only be explained simply by water pumping in the basin. An overestimation of the river flow would lead to an overestimation of the filling efficiency of small farm dams, and to a reduced impact of small farm dams on the river flow. Therefore, the impact of small farm dams on the river flow of the Layon River could possibly be greater than computed in this study. The error between the observed discharge and the discharges simulated by SIM varied in space but with no clear spatial pattern (Habets et al., 2008). Therefore, the distinction between the strongly impacted regions (Pays de la Loire and the Seine Basin) and the less impacted regions (south-western France, Brittany), which is driven by the spatial distribution of precipitation, is expected to be robust. This result is consistent with the analysis of Shao et al. (2012), who found that the dams were more widespread in regions with substantial precipitation in winter and moderate slopes.

Strong hypotheses were also made on the spatial extent of small farm dams and their associated storage. Given that several spatial coverages were tested, the estimated volume should be discussed. The volume of water stored in the dams was simply estimated using an assumed water depth of $3 \mathrm{~m}$. However, previous studies have found a non-linear relationship between the volume capacity and the surface area: $V=\alpha A^{\beta}$, with $V$ the volume and $A$ the area (Hughes and Mantel, 2010; Shao et al., 2012, for instance). According to the relationship used in Shao et al. (2012), it appears that the $3 \mathrm{~m}$ depth is the lower boundary and corresponds to very small farm dams. However, the $3 \mathrm{~m}$ depth was used because it corresponds to the average depth of 171 small farm dams in south-western France, and it is thought to be more appropriate to the context in France. Moreover, sensitivity to the volume was assessed indirectly by considering several values of the area of the dams as discussed above. A better relationship between volume and surface area of the dams might have led to different values being considered for their areas. In our study, the dam's area was only sensitive via its impact on the storage volume, because the increased evaporation from the dams was neglected. More precisely, evaporation from dams was considered to be equal to the evapotranspiration from the surrounding environment. Since evaporation from a water body is close to potential evaporation, the evaporation loss during the filling period was probably underestimated, especially for the 5-month filling period. Moreover, after the filling period, the evaporation losses from small farm dams reduce the volume stored, and thus the ability of small farm dams to supply water to farmers is certainly overestimated in our simulations. Martínez-Granados et al. (2011) quantified the evaporation in a semi-arid region of Spain, and they estimated that the evaporation loss could reach $8 \%$ of the water stored. As most of France has a wetter climate, it can be considered that the loss will be lower in France and that the stored water volume would decrease by less than $8 \%$ due to evaporation loss.

Another issue is that the water from dams is expected not to have any feedback on the river flow, i.e. it is assumed to evaporate on the fields. According to the scenarios reported herein, the water stored would represent $15-30 \mathrm{~mm} \mathrm{~m}^{-2}$ of irrigation water, which would be used in summer ( 3 months) over the entire basin. Although these are small quantities that can easily evaporate in summer, given that only part of the basin is irrigated, they can still impact autumn runoff. However, the impact should be very limited at the beginning of the filling period, i.e. in November. Therefore, its influence on the study is expected to decrease.

\section{Conclusions}

The main objective of this study was to gain an understanding of the maximum storage capacity of small farm dams that would be sustainable over time and have a limited impact on the Pays de la Loire region. A simple modelling approach was set up, showing that the development of small farm dams should be more limited in the Pays de la Loire region, and also in the Seine Basin, compared to other regions of France, because the hydroclimatic conditions are not favourable. In these regions, the dams are less able to fill and thus to supply water to farmers; additionally, the presence of the dams leads to a greater decrease in flow than in other regions. The impact of such dams is exacerbated during dry years, even though they are only filled to approximately $50 \%$ 

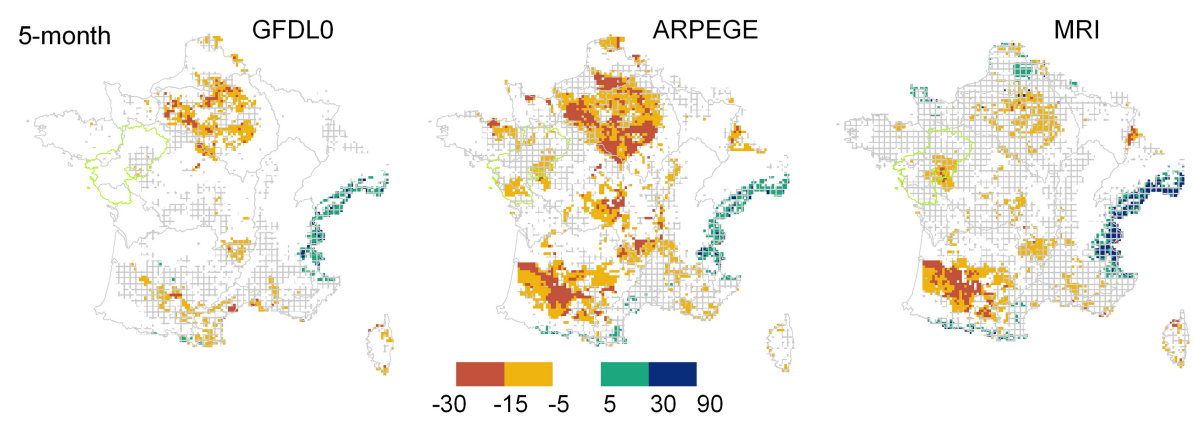

Evolution of the mean storage in 2050
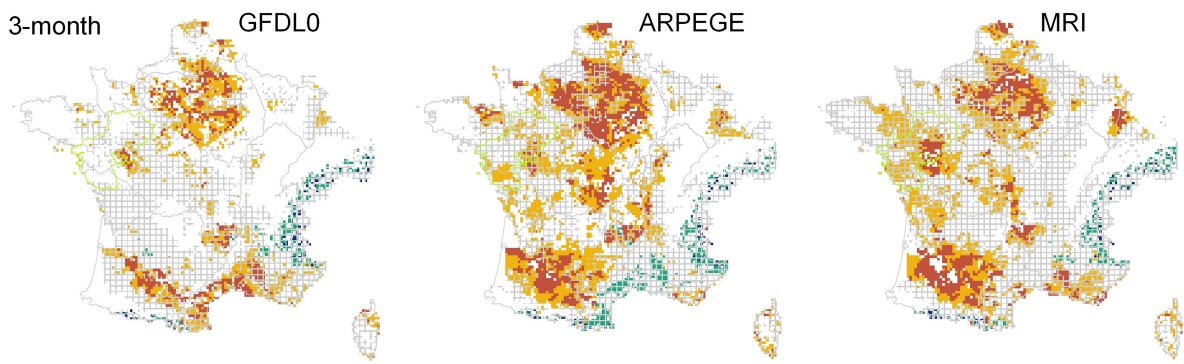

Figure 15. Evolution of the mean maximum storage of small farm dams in 2050 as projected using three downscaled climate projections for the two filling periods. Results that are not significant at the $95 \%$ level are hatched.

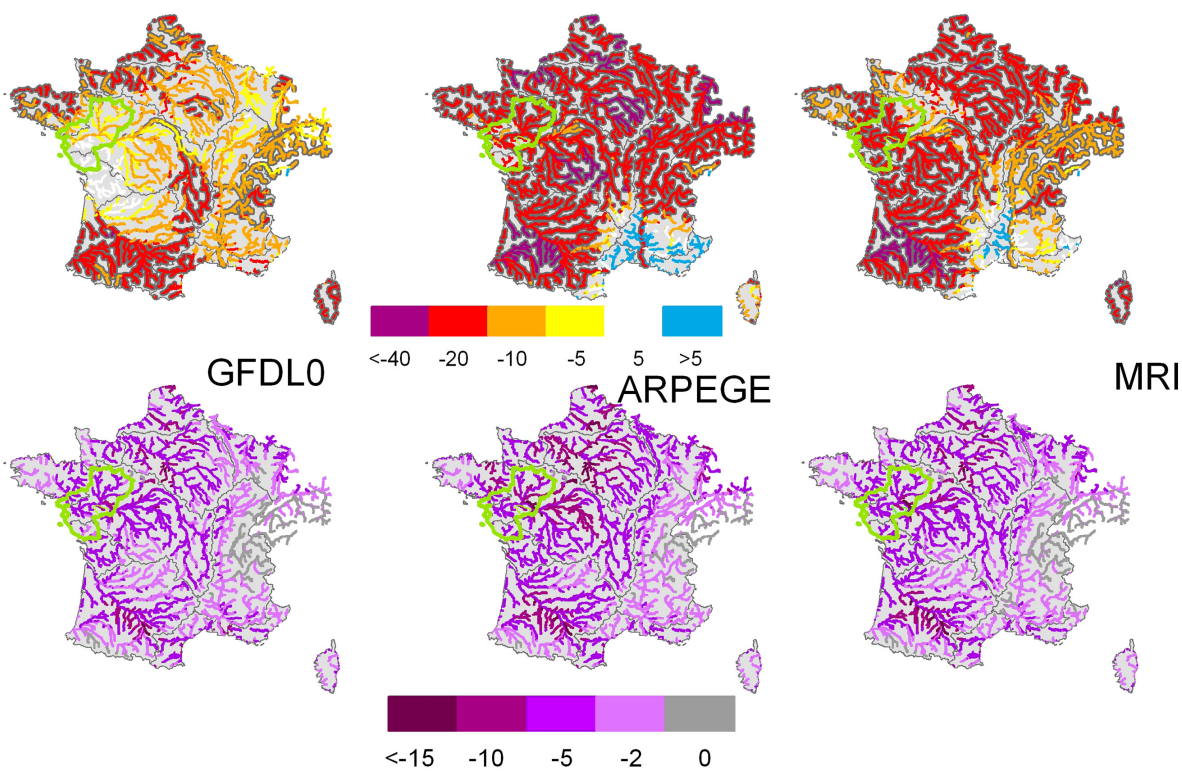

Figure 16. Impact of climate change (top) and small farm dams (bottom) on the annual discharge in 2050 as projected using three downscaled climate projections (in \%). Small farm dams are assumed to cover $0.5 \%$ of the area, with a catchment that covers half the basins, and the filling period is taken as 5 months. Top, changes that are significant at the $95 \%$ level are outlined in black. Bottom, the distinction is not made because only a few river cells gave results significant at the $95 \%$ level.

in these regions. The study gives some qualitative answers to the main questions of the regional environmental agency: the full storage capacity of the dams should be limited (perhaps around 15000 but more likely less than $30000 \mathrm{~m}^{3} \mathrm{~km}^{-2}$ ) in the Pays de la Loire region in order to ensure good filling efficiency even in a dry year. Limiting the filling period to 3 months would have a positive impact on the flow but would decrease the efficiency of the dam filling and thus the ability of the dams to provide water in water shortage periods. This ability is projected to decrease in a context of climate change.

The study found that the regions that are sensitive to filling failure and have a considerable impact on today's river flow 
(Pays de la Loire, Seine Basin) are projected to have greater difficulties in the future in a context of climate change. This reinforces the sensible idea that adaptation to climate change begins with adaptation to present-day extremes.

Acknowledgements. This study was supported by the DREAL Pays de la Loire. We would like to thank Stéphanie Poligot-Pitsch for her assistance, as well as Michel Déqué from CNRM-GAME and Christian Pagé and Laurent Terray from Cerfacs for providing the downscaled climate projections. We are grateful to Patrice Dumas and the anonymous reviewer for their comments that helped to improve this article.

Edited by: N. Basu

\section{References}

Albergel, J., Nasri, S., and Lamachère, J.-M.: Project of research on hill reservoirs in the semi arid zone of Mediterranean periphery, Revue des Sciences de l'Eau, 17, 133-151, 2004.

Amigues, J. P., Debaeke, P., Itier, B., Lemaire, G., Seguin, B., Tardieu, F., and Thomas, A.: Sécheresse et agriculture, Réduire la vulnérabilité de l'agriculture á un risque accru de manque d'eau, Expertise scientifique collective, synthèse du rapport, INRA (France), 72 pp., 2006.

Bhagat, V. S. and Sonawane, K. R.: Use of Landsat ETM+ data for delineation of water bodies in hilly zones, J. Hydroinform., 13, 661-671, 2011.

Boé, J., Terray, L., Habets, F., and Martin, E.: A simple statisticaldynamical downscaling scheme based on weather types and conditional resampling, J. Geophys. Res.-Atmos., 111, D23106, doi::10.1029/2005JD006889, 2006.

Boé, J., Terray, L., Martin, E., and Habets, F.: Projected changes in components of the hydrological cycle in French river basins during the 21st century, Water Resour. Res., 45, W08426, doi:10.1029/2008WR007437, 2009.

Casas, J., Toja, J., Bonachela, S., Fuentes, F., Gallego, I., Juan, M., León, D., Peñalver, P., Pérez, C., and Sánchez, P.: Artificial ponds in a Mediterranean region (Andalusia, southern Spain): Agricultural and environmental issues, Water Environ. J., 25, 308-317, 2011.

Chauveau, M., Chazot S., Perrin, C., Bourgin, P.-Y., Sauquet, E., Vidal, J.-P., Rouchy, N., Martin, E., David, J., Norotte, T., Maugis, P., and de Lacaze, X.: Quels impacts des changements climatiques sur les eaux de surface en France á l'horizon 2070?, La Houille Blanche, 4, 5-15, doi:10.1051/lhb/2013027, 2013.

Cudennec, C., Sarraza, M., and Nasri, S.: Robust modelling of the aggregated impact of small headwater dams on surface hydrology, Revue des Sciences de l'Eau, 17, 181-194, 2004.

David, C. H., Maidment, D. R., Niu, G.-Y., Yang, Z.-L., Habets, F., and Eijkhout, V.: River network routing on the NHDPlus dataset, J. Hydrometeorol., 12, 913-934, 2011 a.

David, C. H., Habets, F., Maidment, D. R., and Yang, Z.-L.: RAPID applied to the SIM-France model, Hydrol. Process., 25, 34123425, $2011 b$.

Durand, Y., Brun E., Merindol, L., Guyomarc'h, G., Lesaffre, B., and Martin, E.: A meteorological estimation of relevant parame- ters for snow models, Ann. Geophys., 18, 65-71, 1993, http://www.ann-geophys.net/18/65/1993/.

FNSEA (Fédération Nationale des Syndicats d'Exploitants Agricoles) La cohérence gouvernementale prend l'eau, http: //www.fnsea.fr/media/445696/communiquestockageeaufinal.pdf (last access: 27 October 2014), 2012.

Galéa, G., Vasquez-Paulus, B., Renard, B., and Breil P: L'impact des prélèvements d'eau pour l'irrigation sur les régimes hydrologiques des sous-bassins du Tescou et de la Séoune (bassin Adour-Garonne, France), Revue des sciences de l'eau, Journal of Water Science, 18, 273-305, 2005.

Giuntoli, I., Renard, B., Vidal J.-P., and Bard, A.: Low flows in France and their relationship to large-scale climate indices, J. Hydrol., 482, 105-118, 2013.

Güntner, A., Krol, M. S., de Araújo, J. C., and Bronstert, A.: Simple water balance modelling of surface reservoir systems in a large data-scarce semiarid region, Hydrol. Sci. J., 49, 901-918. 2004.

Habets, F., Boone, A., Champeaux, J. L., Etchevers, P., Franchistéguy, L., Leblois, E. Ledoux, E., Le Moigne, P., Martin, E., Morel, S., Noilhan, J., Quintana-Seguì, P., RoussetRegimbeau F., and Viennot, P.: The SIM hydrometeorological model over France, J. Geophys. Res., 113, D06113, doi:10.1029/2007JD008548, 2008.

Habets, F., Boé, J., Déqué, M., Ducharne, A., Gascoin, S., Hachour, A., Martin, E., Pagé C., Sauquet, E., Terray L., Thiéry, D., Oudin, L., and Viennot, P.: Impact of climate change on the hydrogeology of two basins in Northern France, Climatic Change, 121, 771-785, doi:10.1007/s10584-013-0934-x, 2013.

Hébert, N. Grandmougin, B., Loubier, S., Graveline, N., Marsac, S., Amen, J.-F., and Brunel, L.: Water withdrawal policy reform in the Adour-Garonne basin: economic impacts on the farming sector Agronomie, Environnement et Sociétés, 2, 113-126, 2012.

Hughes, D. A. and Mantel, S. K.: Estimating the uncertainty in simulating the impacts of small farm dams on streamflow regimes in South Africa, Hydrol. Sci. J., 55, 578-592, 2010.

Khlifi, S., Ameur, M., Mtimet, N., Ghazouani, N., and Belhadj, N.: Impacts of small hill dams on agricultural development of hilly land in the Jendouba region of northwestern Tunisia, Agr. Water Manage., 97, 50-56 2010.

Ledoux, E., Gomez, E. Monget, J. M., Viavattène, C., Viennot, P., Ducharne, A., Benoit, M., Mignolet, C., Schott, C., and Mary, B.: Agriculture and groundwater nitrate contamination in the Seine basin. The STICS-MODCOU modelling chain, Science Tot. Env., 375, 33-47, 2007.

Martínez-Granados, D., Maestre-Valero, J. F., Calatrava, J., and Martínez-Alvarez, V.: The economic impact of water evaporation losses from water reservoirs in the Segura basin SE Spain, Water Resour. Manage., 25, 3153-3175, 2011.

Masson, V., Champeaux, J.-L., Chauvin, F., Meriguet, C., and Lacaze, R: A Global Database of Land Surface Parameters at $1 \mathrm{~km}$ Resolution in Meteorological and Climate Models, J. Climate, 16, 1261-1282, 2003.

Malveira, V. T. C., de Araujo, J. C., and Güntner, A.: Hydrological Impact of a High-Density Reservoir Network in Semiarid Northeastern Brazil, J. Hydrol. Eng., 17, 109-117, 2012.

MEDD (Ministère de l'Ecologie, du Développement durable, des Transports et du Logement) Guide Juridique, Construction de retenue, 50 pp., 2009. 
Nathan, R. and Lowe, L.: The hydrologic impacts of farm dams, Australian J. Water Res., 16, 75-83, 2012.

Nash, J. and Sutcliffe, J.: River forecasting using conceptual models, 1. A discussion of principles, J. Hydrol., 103, 282-290, 1970.

Noilhan, J. and Planton, S.: A simple parameterization of Land Surface Processes for meteorological Models, Mon. Weather Rev., 117, 536-549, 1989.

Pagé, C., Terray, L., and Boé, J.: Projections climatiques à échelle fine sur la France pour le 21ème siècle : les scénarii SCRATCH08, CERFACS, 21 pp., 2008.

Quintana-Seguì, P., LeMoigne, P., Durand, Y., Martin, E., Habets, F., Baillon, M., Franchisteguy, L., Morel, S., and Noilhan, J.: The SAFRAN atmospheric analysis: Description and validation, J. Applied Meteorol. Clim., 47, 92-107, 2008.

Quintana Seguí, P., Martin, E., Habets, F., and Noilhan, J.: Improvement, calibration and validation of a distributed hydrological model over France, Hydrol. Earth Syst. Sci., 13, 163-181, doi:10.5194/hess-13-163-2009, 2009.

Quintana-Seguì, P., Ribes, A., Martin, E., Habets, F., and Boé, J.: Comparison of three downscaling methods in simulating the impact of climate change on the hydrology of Mediterranean basins, J. Hydrol., 383, 111-124, 2010.

Ramireddygari, S. R., Sophocleous, M. A., Koelliker, J. K., Perkins, S. P., and Govindaraju, R. S.: Development and application of a comprehensive simulation model to evaluate impacts of watershed structures and irrigation water use on streamflow and groundwater: The case of Wet Walnut Creek Watershed, Kansas, USA, J. Hydrol., 236, 223-246, 2000.

Rodrigues, L. N., Sano, E. E., Steenhuis, T. S., and Passo, D. P.: Estimation of small reservoir storage capacities with remote sensing in the Brazilian savannah region, Water Resour. Manag., 26, 873-882, 2012.
SAGE (Schéma d'Amaénagement et de Gestion des Eaux) des bassins Versants du Layon et de l'Aubance, Phase I: Rapport, 163 pp., 2002 a.

SAGE (Schéma d'Amaénagement et de Gestion des Eaux) des bassins Versants du Layon et de l'Aubance, Phase II: Elaboration des scénarios, 75 pp., 2002 b.

SDAGE (Schéma Directeur d'Amaénagement et de Gestion des Eaux) du bassin Loire-Bretagne 2010-2015, 252 pp., 2009.

Shao, Q., Chan, C., Jin, H., and Barry, S.: Statistical Justification of Hillside Farm Dam Distribution in Eastern Australia, Water Resour. Manag., 26, 3139-3151, 2012.

van der Velde, M., Tubiello, F. N., Vrieling, A., and Bouraoui, F.: Impacts of extreme weather on wheat and maize in France: Evaluating regional crop simulations against observed data, Clim. Change, 113, 751-765, 2012.

Vidal, J.-P., Martin, E., Franchistéguy, L., Baillon, M., and Soubeyroux, J.-M.: A 50-year high-resolution atmospheric reanalysis over France with the Safran system, I. J. Climatol., 30, 1627 1644, 2010a.

Vidal, J.-P., Martin, E., Franchistéguy, L., Habets, F., Soubeyroux, J.-M., Blanchard, M., and Baillon, M.: Multilevel and multiscale drought reanalysis over France with the Safran-Isba-Modcou hydrometeorological suite, Hydrol. Earth Syst. Sci., 14, 459-478, doi:10.5194/hess-14-459-2010, 2010.

Vidal, J.-P., Martin, E., Kitova, N., Najac, J., and Soubeyroux, J.M.: Evolution of spatio-temporal drought characteristics: validation, projections and effect of adaptation scenarios, Hydrol. Earth Syst. Sci., 16, 2935-2955, doi:10.5194/hess-16-29352012, 2012. 